\title{
Names from The Magic Mountain
}

\section{WARREN R. MAURER}

$\mathrm{P}_{\mathrm{n}}$

ROBABLY THE SHORTEST AND BEST DESCRIPTION of the formal aspects of Thomas Mann's Zauberberg (1924) is the unusual compound Romanteppich, or "tapestry novel." This term, used by Mann himself, ${ }^{1}$ suggests a work of art consisting of a great number of colorful strands, skillfully interwoven in such a way that each one touches or crosses many others and contributes distinctly to the completed picture. My purpose in this study will be to focus attention on a much neglected, multicolored strand of Mann's composition - the character names. Through the use of examples I shall try to show something of the complexity of considerations the author had in mind while naming his characters, and the relationship of the names to other elements of the novel such as plot, leitmotif, characterization, and numeric symbolism.

Even a superficial reading of the novel in German leaves one with the impression that the names are generally significant on several levels, and that the connotations attached to them are at once subtle and playful. A rereading, with special attention to names, allows the reader, in many cases, to confirm his suspicions as to what Mann wishes to imply with a particular name. With surprising frequency he offers clues to his own attitude through the characters, through narration, and through the use of such stylistic devices as the description of dreams and the use of indirect discourse.

A reasonable explanation has already been given for the name of the "simple hero" of the book, Hans Castorp. Wolff, doubtlessly recalling the line where Hans and his cousin Joachim are greeted as "Castor und Pollux,",2 concludes that Mann had the Greek myth in

${ }^{1}$ I. e., in "Der Tod in Venedig" (1911). See Thomas Mann, Novellen (Berlin, 1925), 2.356. Cf. also Hermann J. Weigand, Thomas Mann's Novel Der Zauberberg (New York and London, 1933), 166-167, note 16.

2 Thomas Mann, Der Zauberberg, (2 vols., Berlin, 1924), 1.363. Subsequent quotations from the novel in my text are from this edition. The parallel English translations supplied where necessary are basically my own although I also consulted the H. T. Lowe-Porter translation (New York, 1939). See also Hans M. Wolff, Thomas Mann (Bern, 1957), 60. 
mind when he named his hero. By adding a $p$ to the name Castor he makes the possibility of recognition more remote, while producing a name which looks German, and which is suitable for a member of the upper middle-class of northern Germany. Through the uninhibited mispronunciation of a minor character, Mann characterizes the name as such, but also indicates the slightly peculiar sound it nevertheless has for a German. Frau Zimmermann says to Castorp: "Setzen Sie sich doch, Herr Kasten, Herr Carsten, oder wie Sie heißen, Sie heißen so komisch..." (1. 515; "Sit down, Mr. Kasten, Mr. Carsten, or whatever your name is, you have such a funny name..."). By contrasting Castorp's name with two which are entirely German the implication is made that it is not quite typical and that its bearer is not quite typical either. Adding the $p$ must have been satisfying to the author for another reason too. It gives the name Castorp seven letters and thereby links it with the sevensymbolism so prominent in the book. Although not all of the names have seven letters, most of the main ones and too many of the minor do, to be ascribed to coincidence in the work of such a meticulous craftsman. ${ }^{3}$

Joachim Ziemßen, Castorp's cousin and inseparable companion, plays the role of Pollux in the narrative, even to the point of returning from the realm of the dead in order to pay him a visit. In naming him, however, Mann abandons the Greek myth in favor of more primary considerations. Joachim is "ein Militär." His bearing is military, he answers questions by clicking his heels, he is assiduously scrupulous of orders (even the house orders of the sanatorium), he makes anti-Semitic utterances, and quotes Moltke on the necessity of war. Instead of opinions he has prejudices. "Ich sage dir ja," he tells Castorp, "es kom mt überhaupt nicht drauf an, was für Meinungen einer hat, sondern darauf, ob einer ein rechter Kerl ist." (2. 77-78, "I tell you it doesn't matter at all what opinions a man has, as long as he's a decent fellow.") In short, he is as the little Italian Settembrini says, "... jene Hoffnung der preußischen Heeresorganisation, Leutnant Ziemßen.” (2. 60, "... that hope of the Prussian army organization, Lieutenant Ziemssen.") It is for this reason, and possibly because the author speaks of "... Joachims capitan general, der preußische Friedrich..."

${ }^{3}$ Cf. A. M. Z. Norman, "Seven Symbolism in The Magic Mountain," Monatshefte, 47 (1955), 360. 
(2. 180) that some critics have seen in Ziemßen the model of Frederick the Great. ${ }^{4}$ The resemblance is tenuous at best. Frederick, with his interests in philosophy and the arts, and his adeptness at intrigue and politics, was a far more complicated individual than the simple, straightforward soldier Joachim. A more fitting and plausible model, it seems to me, is available in the person of the celebrated General Hans Joachim von Zieten (1699-1786). I am led to my conclusion not only by the similarity of the names, or the fact that the "preußische Friedrich" was in reality Zieten's capitan general, but because he epitomizes young Ziemßen's military ideal of unspeculative, manly derring-do, much more perfectly than Frederick the Great himself. Like Ziemßen, his one desire was to be a soldier, and he tried to enlist three times before he was finally accepted for military service. Once in the army he advanced rapidly to the rank of lieutenant (as does Ziemßen) and soon made a name for himself as a courageous field soldier with (again like Ziemßen) a strong antipathy to barracks duty and a predilection for sports and physical activity. That Mann knew this historical personage is virtually certain. Zieten and his famous Zietenritt (Zieten's ride) are household words known to practically every schoolboy in Germany, and the anecdotes told about him are a part of German folklore. Mann, who had earlier made extensive studies for a projected novel about Frederick the Great, probably knew him more intimately than most.

The question remains as to how Mann arrived at the name Joachim Ziemßen from Hans Joachim von Zieten. Joachim, a perfectly serviceable and soldierly name of seven letters, and with Prussian connotations, is, of course, given; an added incentive to his choice may also lie in the fact that one of Mann's ancestors had the name. ${ }^{5}$ The surname would be changed so as not to be too obvious, although the first syllable would be hard to resist. For some reasonperhaps the influence of Zieten himself - names beginning with the letters $Z i(e)$ - are easily associated with Prussian militarism. For example the pre-World War I political-humor magazine Simplizissimus, of which Mann was a one-time editor, demonstrates this repeatedly in its choice of names (such as von Zitzewitz) for the

4 E.g., Ferdinand Lion, Thomas Mann Leben und Werk (Zürich, 1947), 84.

5 I. e., Joachim Siegmund Mann (1728-1799). See Viktor Mann, Wir waren fünf (Konstanz, 1949), 13. 
Prussian military boob. The name Ziemßen would have appealed to him when he saw it, and in Munich, where he lived and worked, he had sufficient opportunity to come in contact with it; it is the name of a street - Ziemssenstrasse - in the center of town. ${ }^{6}$ That he should change the $s s$ to $\beta$, with the same phonetic value, may have been occasioned by the fact that it looks more Prussian, or because it again results in a name with seven letters.

Although the name Settembrini, one of Castorp's mentors and the eloquent but superficial spokesman of enlightenment, has more than seven letters, the suggestion of seven, i.e., September "the seventh month," is inherent in it. The name is ironic. It refers to the September Revolution of 1792, after which the verb septembriser was coined to mean "radical action." Settembrini, however, would have us believe that he is the advocate of a humanistic, evolutionary, parliamentary type of government. His prototype, according to Mann, may have been the Italian liberal politician and literary critic Luigi Settembrini (1813-1877). ${ }^{7}$

Naphta, the name of Castorp's second pedagogue and a competitor with Settembrini for his soul, has more ominous overtones than that of the handsome little "windbag" and "organgrinder." Naphta is also more complex. Physically he is small, sharp of feature, with "metallic colorless" hair and a "corrosive" ugliness. Born a Jew and raised a Jesuit, he is a terrorist living in a "silken cell." As Weigand explains, "his personality, rooted in no steadying tradition, is a discordant blend of motley elements that have coalesced solely because of their mutual bond of hate against the bourgeois world" (p.12). From the colorless, volatile petroleum distillate naphtha the name gets coldly-impersonal and has unpleasant connotations and the suggestion of inflammability. It is not surprising that Naphta, such a precarious unity of opposites, ends by blowing out his brains in a fit of rage. Naphta is also a Jew - with a twice camouflaged Jewish name. The Biblical surname Naphtali is a translation into Hebrew (usually as a device to obscure its bearer's Jewish background) of the more common Hirsch. ${ }^{8}$ By shortening

${ }^{6}$ Named, on January 1, 1903, after Geheimrath Dr. Hugo von Ziemssen (1829 to 1902), a famed clinician and Munich personality.

" See H. W. Rudman, "A Possible Prototype of Mann's Settembrini," GR, 25 (1950), 299. Cf. also Weigand, 164, note 16; and Wolff, 66.

${ }^{8}$ See Ernst Schwarz, "Ruf- und Familiennamen," Deutsche Namenforschung (Göttingen, 1949), 1.207. 
this existing name to Naphta, Mann expanded its connotative value, in the directions discussed above, without losing entirely the suggestion of Hebrew origin. The suggestion that Naphta is hiding his past is also supported by the fact that he has changed his first name from Leib to the less distinctive Leo - a name which Mann, possibly with intentional parallelism, also gives the Jew Leo Blumenkohl.

The first name of Naphta's father, Elia, who is described as "etwas von einem Gottesvertrauten" (2. 167, "something of a confidant of God"), serves, in its allusion to the Prophet Elias (Elijah), to characterize him as belonging to an older generation of mystics, and tempers the harsh impersonal sound of the surname.

Mann also uses several other Jewish names to good advantage in his novel, and one entire incident depends on the reader's recognition of such a name for its understanding: the episode of Rosenheim and Schmitz related by Dr. Behrens. Both names have ironic overtones. Rosenheim, the Jewish name, means "house of roses," and suggests sweetness and tranquillity. It is used to designate a patient in an advanced stage of tubercular decay. Rosenheim's opponent and fellow patient, Schmitz, cherishes a bitter hatred for him and reports him to Behrens for having spat upon the sidewalk. Castorp naïvely blames the mutual antagonism on an affaire de cœur but the author tells the real story simply by contrasting the names. The noun Schmitz, in German, is an alternate form of the more common Schmi $\beta$, which means "dueling scar" and contains all the unpleasant associations of the notorious rightist, antiSemitic "schlagende Verbindungen" or dueling fraternities. Taken together the names speak volumes about the anti-Semitic basis for the conflict between the two men.

Significantly Mann gives us another anti-Semitic episode, but this time, in keeping with the crescendo of emotions near the end of the book where it appears, he dispenses with subtlety and involves the protagonists, Sonnenschein and Wiedemann, in a public hair-pulling, eye-gouging battle. Again the names are ironic. Sonnenschein (i.e. "sunshine") is a friendly, intelligent man with a basically sunny personality. To Wiedemann, the vehement antiSemitic, there is, however, no filthier name. His own name he 
considers "Christian" and "not impure," in spite of the connotations of widerlich (disgusting) it inevitably has for the German reader.

In his ravings Wiedemann speaks of two Jews, Hirsch (stag) and Wolf, which fit into the category of animal names. That Mann also attributes animal characteristics to people with such names is frequently suggested. An Iltis, for example, is a fitchet or European polecat. In one of his dreams Castorp sees the patient Frau Iltis sitting by the side of the road "mit einer spitzen Schnauze" (1. 36, "with a pointed snout"). Another character, a redheaded girl from Greece, he designates only as "die Patientin mit dem Tapirgesicht" (1. 188 and 556, "the patient with the tapir-face"), and the name Gänser, from German Gans 'goose,' aptly describes the silly be havior of its bearer.

Dr. Behrens derives his name from German Bär 'bear' and, lest there by any doubt, Mann has one of the patients call him a "Bär" outright (1.517). Again the name is eminently suitable. It suggests the bearish impression made by his huge hands and feet, flat nose, stooped, broad-legged stance, and robust personality. It even suggests his animalistic, materialistic outlook; for he is indeed a Körperfürst 'prince of the body' as Settembrini once calls him.

Perhaps the most obvious of Mann's animal names is that of Clawdia Chauchat. The pronunciation of the surname tells us that Mann had in mind the French words chaud and chat 'warm [or ardent] cat,' and in numerous comments he suits the character to the name. Her walk is described now as a Katzentritt 'cat's step,' now as that of a kitten slinking to a bowl of milk. Her movements are feline and "lässig" 'indolent.' When she moves about she does so with "vorgeschobenem Kopf" 'head thrust forward,' and her face, which is also that of a "Schleicherin" 'one who slinks,' has, with its wide cheekbones and slanted "Steppenwolfslichter" 'prairiewolf eyes,' the appearance of a cat. Behrens even implies that she speaks like a cat when he asserts "... Französisch oder auch Neuhochdeutsch miaut das Kätzchen ja allerliebst, ..." (2. 23, "... the kitten meows quite prettily in French or book German...").

Mme. Chauchat is the embodiment of carnal love, death, and the mystic East. Although her animal magnetism is stressed on the surface, Mann never allows the reader to forget how closely her 
attraction for Castorp is related to his affinity for death. It is disease, death's helpmate, which emphasizes her body. Her arms are cool as death, and, instead of a photo, Castorp carries a picture of her skeleton, a chest $\mathrm{x}$-ray, next to his heart. To stress this relationship still further the author confuses her, in the hero's psyche, with a former schoolmate named Hippe. Whereas the name Chauchat connotes feverish, pulsating life, Hippe, its complement, connotes death. Hippe is an archaic German word for "scythe," the symbol of the Grim Reaper, familiar to every German reader of Bürger's famed Lenore. ${ }^{9}$

Both Clawdia Chauchat and Pribislav Hippe are of Slavic origin and one might ask why their surnames are not Slavic too. The answer lies in the fact that the author prefers names with associations meaningful to his German audience. For the sake of realism he suggests that Chauchat is a nickname (a fact which only enhances its appropriateness) and that the woman's real name is Russian. The name Clawdia (pronounced Clavdia) Castorp himself finds fitting. Aside from suggesting Klauen 'claws' - another reference to her feline nature - its pronunciation is also Russian enough to keep the reader aware of her Eastern origin. Hippe's first name serves a similar purpose. It is an archaic Czech name well-suited to the archaic surname. It is odd that Pribislav, or "Pschibislav," as Mann insists it should be pronounced, should even have a Slavic first name considering his family's long lineage in Germany. Odd too, that being a western Slav, he should have the same "Kirgisenaugen" 'Kirghiz eyes' as Mme. Chauchat.

In Marusja, diminutive of "Maria," the author successfully imbues a Slavic name with connotations his audience can understand. By stressing the similarity of the sound of the name to that of the word mazurka (1.123), he emphasizes the macabre gaiety of the girl "mit dem Apfelsinenparfüm und der hohen, wurmstichigen Brust" (1. 249, "with the orange scent, and the swelling bosom tainted

${ }^{9}$ Like the Zauberberg, Gottfried August Bürger's poem mingles life, death, and love. The pertinent lines read:

\section{Zum Schädel ohne Zopf und Schopf, \\ Zum nackten Schädel ward sein Kopf, \\ Sein Körper zum Gerippe \\ Mit Stundenglas und Hippe.}

(His head turned into a skull, a naked skull without scalp or queue; his body became a skeleton with hour-glass and scythe.) 
within"). Mann likewise depends heavily on tonal associations for the name of Dr. Krokowski. The first syllable suggests the word crow in both English and Polish, and the man's fluttering black cloak (blood-spattered in one description), yellow teeth, and seemingly air-borne entrance into Castorp's room, suggest a carrion crow. The sound of the name enhances this impression since it too is suspiciously similar to the cry of a crow. That it is at the same time unpleasant, should not, however, prejudice the reader against the opinions of its bearer. Settembrini's name has a more pleasant ring than Naphta's, but Castorp and Mann consider them both "Schwätzer" 'babblers.' Likewise, although Behrens may sound more pleasant, and designates a more likeable character than Krokowski, this is no indication that Mann sides with the former in his physiological interpretation of the cause of disease; quite the contrary. The names merely provide artistic balance.

Assisting the two doctors at Berghof is the nurse Adriatica von Mylendonk. A Catholic, proud of the fact that one of her ancestors was an abbess in a convent at Bonn in the thirteenth century, her name reminds Castorp and the reader of days long gone by. "Von Mylendonk und dann Adriatica," he muses, "Es klingt, als müßte sie längst gestorben sein" (1. 105, "Von Mylendonk and then Adriatica; it sounds as though she must have died a long time ago"). Another nurse, a part-time, private employee, also has an archaic name, but one with less elusive connotations. Alfreda Schildknecht arrives on the scene with her little black bag when all hope for a patient has been abandoned. The champion of the moribundus, she nurses the dying Rotbein and is a frequent visitor to Leila Gerngroß before her death. Her name characterizes her in this capacity. As in the age of chivalry she is a Schildknecht: a 'shield-bearer' or 'squire' who helps her patients bear their burden in the final battle with death. This function becomes especially clear when Ziemßen dies. Always the soldier, he grows a field soldier's beard which enhances the illusion of a dying warrior. At one point Alfreda makes the embarrassing remark in his presence that she had never expected to "serve him to death" (2. 324, "zu Tode pflegen"), and when he finally expires she is at her post in the corridor as though standing guard before his door.

A minor member of the staff, the bath attendant Turnherr, has a name which aptly describes both his occupation and appearance. 
Constructed on the pattern of the nickname of the father of German gymnastics, "Turnvater" Jahn, ${ }^{10}$ it refers in its component parts to gymnastics and master or Mr. and reeks of locker rooms and physical fitness cults. It is an excellent name for the "nerviges Individuum" 'muscular individual' who gives Castorp his rubdown.

Several other names are also striking as designators of particular professions. Stern old Pastor Hesekiel has as his surname an older variant of the name of the Prophet Ezechiel (Ezekiel). Mann emphasizes the dignity of the name, of the man, and of his age, by contrasting them with the colorless name of Hesekiel's more modern successor, Pastor Bugenhagen. The family doctor, Dr. Heidekind, also of an older generation, has a name which suggests several equally apt interpretations. It may be construed to mean either 'child of the heath' or 'heathen child.' Since, however, it also has strong connotations of Heidekraut, and since Kraut 'herb' belongs to the realm of primitive, heathen medicine, the latter explanation seems to me most fitting. Heidekind's methods, at any rate, are far simpler and more child-like than the specialized medical techniques of Behrens and Krokowski. For Castorp's illness he prescribes porter and a change of climate! The care Mann often lavishes on names of even minor characters is further exemplified by Stabsarzt 'staff doctor' Eberding, mentioned only once. In its literal meaning of 'boar-pig thing' this name hints ungently at the crudity of army doctors.

Occasionally the author uses names in a manner very suggestive of the technique of the leitmotif. By the mere mention of such a name he not only elicits a specific reaction from the reader, but is able to transfer the same reaction to characters with whom the reader may be totally unfamiliar. Fräulein Kleefeld (Miss Cloverfield) has such a name. She is the queen bee presiding over one of Haus Berghof's seven tables who arouses young men by whistling at them through her pneumothorax, and who, in her dress, manners, and behavior, represents a particularly crude and earthy form of eroticism. Swarming about her are young men of similar disposition. They include the aforementioned Gänser, and two young gentlemen named Herr Albin and Anton Schneermann; the latter, of course, only until his mother learns of the questionable morality of his companions and rescues him forcibly from the sanatorium. Also seated at Kleefeld's table is Dona Perez, the disputed object of

10 I.e., Friedrich Ludwig Jahn (1778-1852). 
affection of Rosenheim and Schmitz. Although the author doesn't bother to describe her, the mention of her name in connection with Kleefeld's is sufficient to taint her with the stamp of moral laxity.

It is Kleefeld's companion, Herr Albin, who introduces the book "Die Kunst, zu verführen" (1. 459, The Art of Seduction') to his avidly interested fellow-patients. Mann calls him a Laffe 'dandy' and Windbeutel 'windbag' and emphasizes his affected manner and speech (See 1.136 and 187). The name suggests the adjective albern 'silly' and it seems safe to say that this is at least one of the associations Mann wished to convey by its use.

Frau Stöhr is an older woman with a function similar to Kleefeld's. She is a stingy, cowardly, superstitious gossip with an interest in eroticism and cheap films. Her name and its pronunciation suggest the German words stören 'to disturb' and störrisch 'disturbing, disturbingly.' On several occasions the author describes her "Hasenzähne" 'rabbit teeth' as "störrisch entblößt" 'disturbingly revealed' and speaks of her face and manner as being "störrisch" to Castorp. Her most basic characteristic, however, is that she is "ungebildet" 'uncultured' and/or 'uneducated' and seemingly proud of the fact. A "Hausfrau" from Cannstadt, she constantly mispronounces words, thinks that "Leise, leise, fromme Weise" comes out of Tannhäuser, and speaks of the Erotika (sic) of Beethoven. The German word Störfrau (note the juxtaposition of elements) suggests effectively this side of her nature. A Störfrau is a woman, generally of low social standing, who does day work in people's homes. It is hardly surprising, then, that Frau Stöhr is able to disguise herself particularly effectively as a charwoman on the night of the carnival. Weigand has pointed out the interesting fact that Mann spares his reader a too direct contact "with this representative of coarse, middle-class pretentiousness," by reproducing her "vulgar gossip ... through the medium of indirect discourse" (p. 19).

Frequently mentioned with Frau Stöhr are Frau Salomon and Frau Magnus - the latter the wife of a beer brewer from Halle. Both names are ironic. Fat Mrs. Salomon can hardly be said to possess the "wisdom of Solomon," and Frau Magnus, who is described as being even more stupid than Frau Stöhr, is hardly the humanist her name implies. Her husband has violent fits of anger and an antipathy to literary art. 
The names Barbara Hujus, Leila Gerngroß, and Fränzchen Oberdank are typical of the ones Mann gives the very young female patients. Hujus is derived from the genitive of the Latin demonstrative pronoun hic (usually spelled huius and hujus) and alludes both to the Catholic rite of extreme unction the girl is about to receive and to the fact that she is a "Backfisch" 'adolescent', Latin being the main preoccupation of German secondary school pupils. Poor little Leila Gerngroß (like-to-be-big) with the forget-me-not eyes would also like very much to outlive her adolescence. Unfortunately her first name, with its tonal allusion to Lilien 'lilies' suggests an early death as her lot. Fränzchen Oberdank is a less sentimental and less appealing young lady. The surname implies haughtiness (i.e., "von oben herab") and the diminutive form of the first name suggests a spoiled child. That the lawyer Einhuf 'one-hoof' from Jüterborg should succeed in seducing her is not surprising. Morality is not her strong point, and then, as Einhuf's name implies, he is a "devil" with the ladies. One of the identifying features of the devil in German folklore is that he has a Pferdefuß or horse's hoof.

Of a more sinister nature is Herr Wehsal. A sadist-masochist with bad teeth, whose hobby is making excursions to medieval torture chambers, Wehsal finds his most profound pleasure in self-abasement, thoughts of murder, and the "unlimited happiness" of unrequited love. His admiration for Frau Chauchat is a "Lustfolter" 'pleasure-rack' for him, but, unlike Castorp and Peeperkorn, he comes into contact with her only in his dreams. "Und immer endet es damit," he says, "daß sie mir Ohrfeigen gibt, mich ins Gesicht schlägt und manchmal auch anspeit, - mit vor Ekel verzerrtem Seelenangesicht speit sie mich an, und dann wache ich auf, mit Schweiß und Schmach und Lust bedeckt..." (2. 465, "And all the dreams end the same way: she boxes me on the ears, slaps my face, sometimes spits on me, with her face all distorted in disgust, and then I awake, covered with sweat and shame and desire..."). The noun Wehsal, from which Mann doubtlessly derived the name, signifies "a condition which causes serious sorrow or misery." However, through analogy with such words as Zahnweh 'toothache,' Kopfweh 'headache,' and Wehen 'labor pains,' the stem Weh-also has strong connotations of intense physical pain, and therefore gives the name Wehsal a double suitability. 
I have postponed the discussion of Mynheer Pieter Peeperkorn, because his name, like his character, does not conveniently fit into any category. Peeperkorn is a "Kolonial-Holländer, ein Mann von Java, ein Kaffeepflanzer" (2. 346), with a Malayan servant, a catarrhal condition due to alcoholism, and an interest in beautiful women and deadly poisons. His liquid "bread," for which he has an extraordinary need, is "Schnaps," a "Korndestillat" 'grain distillate,' and in his person he combines attributes of both Bacchus and Jesus in Gethsemane, the "Man of Sorrows." His name suggests all these things. Peeperkorn is Dutch for 'pepper kernel' and suggests the exoticism of faraway places where, as the German says, "der Pfeffer wächst" (pepper grows). Since Korn in German is synonymous with "hard liquor" the second member of the compound, -korn, also connotes the Bacchus side of his personality. Finally, the first name Pieter (Peter) seems to allude to Simon Peter, Gethsemane, and the "Man of Sorrows."11

The above examples illustrate the meticulous care with which Mann chose or invented his fascinating character names. Whether based on Greek mythology, history, the Bible, Latin grammar, word play, folklore, or the animal, vegetable, and mineral realms, they comprise an important strand of the Romanteppich Zauberberg and, at the same time, point up the need for further detailed study of the names from his other works as well. Although such investigation can provide intimate and valuable insights into the creative process, Germanists have, in the past, been curiously neglectful of this revealing facet of literary art. With the exception of a few sporadic footnotes, very little has been written about character names in German literature, and even such blatantly apparent objects for onomastic research as the novels of Franz Kafka, Theodor Fontane, and Hermann Hesse continue to lie fallow. ${ }^{12}$

\section{University of California, Berkeley}

11 In its form it also suggests Pietà, and it is perhaps not a coincidence that an actual Pietà is described so lucidly in the novel. See R. Eis and K. S. Guthke, "Naphtas Pietà," GQ, 33 (1960), 220-223.

12 At this writing, however, a study by Professor J. Mileck of the names in Hesse's Lauscher, Demian, Steppenwolf, and Glasperlenspiel has been completed and was scheduled to appear in the spring of 1961 in Monatshefte. 